\title{
The potential teratogenic effects of interferon beta-1a and interferon beta-1b on in vitro embryonic development
}

\author{
i. Uçar ${ }^{1}$, T. Ertekin², M. Nisari², D. Ceylan³ ${ }^{3}$ Ö. Al ${ }^{2}$, H. Ülger ${ }^{2}$ \\ ${ }^{1}$ Department of Physical Therapy and Rehabilitation, Ahi Evran University, Kırsehir, Turkey \\ ${ }^{2}$ Department of Anatomy, University of Erciyes, Kayseri, Turkey \\ ${ }^{3}$ Genome and Stem Cell Center, University of Erciyes, Kayseri, Turkey
}

[Received: 30 July 2015; Accepted: 27 October 2015]

\begin{abstract}
Background: Interferon beta (IFN $\beta$ ) was the first proven drug for the treatment of multiple sclerosis (MS). The diagnosis of MS frequently occurs in women at childbearing age (especially in twenties and thirties). Therefore, the pregnancy process is major concern for many women with MS. Data on women exposed to IFN $\beta$ during pregnancy are limited. The aim of our study was to investigate the teratogenic potential of IFN $\beta$ on embryonic development via embryo culture technique. Recently, this technique has been often used for determining teratogenic effect of pharmacologic drugs and potential teratogens on embryonic development.

Materials and methods: In this study, IFN $\beta$ was applied to the culture medium and after $48 \mathrm{~h}$ of culture effects of IFN $\beta$ S (1000 IUIIFN $\beta$-1a and 1000 IUIIFN $\beta$-1 $1 \mathrm{~b}$ ) on embryonic development were morphologically investigated.

Results: According to morphologic scoring system, total morphologic score, somite number and protein contents were similar between control group and two experimental groups $(p>0.05)$. On the other hand, yolk sac diameter, crown-rump length and head length were significantly decreased in two experimental groups compared with control group $(p<0.05)$.

Conclusions: Consequently, IFN $\beta$-1 1 and IFN $\beta$-1b, applied to the culture medium, have no macroscopic teratogenic effect on embryonic development. However, in respect of morphometric measurements, IFN $\beta$-1 a and IFN $\beta$ - 1 b have caused growth retardation in embryo. This research related to interferon was the first study using vitro embryo culture technique; thus, in our point of view, future studies which will be performed by using different doses of IFN will contribute to the literature. (Folia Morphol 2016; 75, 2: 257-263)
\end{abstract}

Key words: interferon $\beta-1 \mathrm{a}$, interferon $\beta$-1 b, whole rat embryo culture

\section{INTRODUCTION}

Multiple sclerosis (MS) is a chronic demyelinating, inflammatory, neurodegenerative and neuroimmune disorder that affects white matter of central nervous system [16]. MS is the most common neurologic disease among young adults, typically starting in the third and fourth decades of life. Women are more frequently affected than men $[6,46]$. Recent epidemiological studies have demonstrated that the ratio of female/male is gradually increasing worldwide. Thus, MS especially affects women at childbearing age $[13,35,37]$. The status of the embryo affected by the disease, the manner of drug treatment and uncertainties regarding the mechanisms of drug action

Address for correspondence: T. Ertekin, PhD, Associate Professor, Department of Anatomy, University of Erciyes, School of Medicine, Kayseri, 38039, Turkey, tel: 0090505 6482854, fax: 009035243752 85, e-mail: tolga.ertekin@yahoo.com.tr 
in the process of childbirth and breastfeeding made the pregnant women with MS anxious. Pregnancy has no adverse effects on the course of MS $[9,34$, 44]. According to the current literature, it has not been determined whether an increase in miscarriage, stillbirth, malformations and birth complications is related to MS [34, 39].

Interferon beta- $1 \mathrm{~b}$ (IFN $\beta$ - $1 \mathrm{~b}$, Betaferon/Betaseron) was the first drug approved for the treatment of MS by Food and Drug Administration (FDA) in 1993 [21, $22,43]$. Later, interferon beta-1a (IFN $\beta-1 a$, Avonex/Rebif) was approved for the treatment of Relapsing-Remitting Multiple Scleros. IFN $\beta$ also received approval to treat Secondary Progressive Multiple Sclerosis in some countries [25]. Interferon (IFN) was discovered accidentally by Alick Isaacs and Jean Lindenmann in 1957 [20]. IFNs are located within the family of glycoproteins known as cytokines. They are water-soluble and endogenous substances, with molecular weight of 17-25 kilodaltons (kDa). IFNs are produced naturally by the several cells such as erythrocytes, fibroblasts, epithelial cells and natural killer cells, in response to bacteria, viruses, parasites and tumour cells. IFNs have a very wide antiviral spectrum [24].

A vast number of different IFN molecules were detected in human cells. IFNs were classified among three classes: type I IFN, type II IFN, and type III IFN. The mammalian type I IFNs are designated IFN- $\alpha$ (alpha), IFN- $\beta$ (beta), IFN- $\kappa$ (kappa), IFN- $\delta$ (delta), IFN- $\varepsilon$ (epsilon), IFN- $\tau$ (tau), IFN-o (omega), and IFN- $\zeta$ (zeta, also known as limitin) [15]. A mature IFN $\beta$ protein was composed of 145 amino acids [5]. IFN $\beta$ has two subtypes namely IFN $\beta-1$ a and IFN $\beta-1$ b. Recently, both interferons have a common use in clinics [10]. IFNs were reported to have antiviral, antiproliferative, immunomodulatory and anti-apoptotic activity [21]. Besides, they have effects on the regulation of cell growth and differentiation [41].

Experimental and clinical studies have revealed that IFN $\beta$ decreased the progression of MS by reducing relapse rate, frequency and inflammatory indicators on magnetic resonance imaging (MRI) [27]. However, the mechanism of IFN $\beta$ action in the treatment of MS has not been elucidated yet [26]. Recently, studies have focused on the immunomodulatory and antiproliferative effects of IFN $\beta$ [41]. For the women at childbearing age with MS, it is important to decide to have a planned pregnancy. Otherwise, they will continue to use their medications during pregnancy which may negatively affect the health of the embryo.
In terms of a planned pregnancy, the physicians recommend to quit the prescribed medication 3 months before conception $[8,12]$.

Several studies showed that using IFN $\beta$ during the first 3 months of pregnancy increased the risk of stillbirth and low birth weight $[2,4]$. However, there are limited studies investigating their teratogenic effects during pregnancy, thus IFN $\beta$ - $1 \mathrm{a}$, IFN $\beta$ - $1 \mathrm{~b}$ have received category C by FDA [12].

The in vitro culture technique was described by New and Stein in 1964 [in 42]. Recently, this method has been commonly used to determine the effects of pharmacological agents, hormones, chemical and physical factors on the embryonic development and to determine potential teratogens [30]. The in vitro culture of post-implantation rat embryos during the early organogenesis period (from 9.5 to 11.5 pregnancy days) makes it possible to determine risk of teratogenicity in homologous serum [11]. The present study was performed to clarify the in vitro effects of IFN $\beta-1 \mathrm{a}$ and IFN $\beta-1 \mathrm{~b}$ on embryonic development during the organogenesis period in the rat.

\section{MATERIALS AND METHODS}

This study was approved by the Experimental Animals Ethics Committee of Erciyes University, Turkey (The Ethics Committee Number: 12/101). Wistar rats were used and obtained from the Clinical and Experimental Research Centre, Medical Faculty of Erciyes University. The female rats (approximately 8 weeks of age and weighing $150-250 \mathrm{~g}$ ) were kept in cages as three groups. The males of the same strain were housed singly in mating cages. Male and female rats were placed together in the evening (one pair per cage), and the presence of a vaginal plug the following morning was taken to indicate mating had occurred.

On the assumption that mating occurred around mid-night, the female was considered to be 0.5 day pregnant at noon in the following day. The pregnant rats were sacrificed by overdose ether at 9.5 days of gestation, between 9 a.m. and 10 a.m. in the morning and the embryos were removed from the mother by the procedure described by New [28]. We used 3 dams for each group (totally 9 dams). Using a dissection microscope, the decidual mass was split to expose the conceptus, which was gently teased free and immediately immersed in Hank's balanced salt solution. The damaged and underdeveloped embryos were discarded. There were 4 to 5 embryos in each bottle which contained $1 \mathrm{~mL}$ of immediately centri- 
fuged, heat inactivated whole rat serum (WRS) per embryo and these embryos were randomised from several rats.

In order to assess the effect of the IFN $\beta$-1a (Avonex) and IFN $\beta$ - $1 \mathrm{~b}$ (Betaferon) on total embryonic growth, embryos were divided into three groups (10 embryos in control group and 9 embryos per two experimental groups). The control group embryos were cultured in WRS. The administration dosages of IFN $\beta-1 \mathrm{a}$ and IFN $\beta$ - $1 \mathrm{~b}$ were determined according to the data from previous cell culture studies [47]. For the experimental groups, 1000 IU IFN $\beta$ - $1 \mathrm{a}$ and 1000 IU IFN $\beta$ - $1 \mathrm{~b}$ were added to WRS. After $48 \mathrm{~h}$ culture period, the embryos from each group were examined under the dissecting microscope and assessed according to the morphological scoring system which takes account of the growth and differentiation of different embryological features, including the appearance of yolk sac circulation, allantois, body flexion, heart, caudal neural tube, hindbrain, midbrain, forebrain, otic system, optic system, olfactory system, branchial arches (bars), maxillary processes, mandibular processes, forelimbs, hindlimbs and somite number [29]. Mean yolk sac diameter, crown-rump length and head lengths were also measured by using ImageJ program (http://rsb. info.nih.gov/ij/docs/index.html). Additionally, protein contents of embryos were determined with using Folin Phenol reagents for all groups [11].

\section{Statistical analysis}

Data of the morphological score and somite number, yolk sac diameter, crown-rump length and head length were statistically analysed. All data sets were subjected to normality test by the Shapiro-Wilk test. Comparison between the groups was performed by the one way analysis of variance (ANOVA; multiple comparisons were carried out with Tukey Test). Statistical significance was set at $p<0.05$. All analyses were performed with the statistical package for scientist (SIGMASTAT) Windows version 3.10.

\section{RESULTS}

The results of the present study revealed the development of the control group embryos were normal and morphological scoring results were close to the development of an 11.5-day in vivo embryo (Fig. 1). The embryos cultured in IFN $\beta$ - $1 \mathrm{a}$ and IFN $\beta$-1 b showed that there was no significant difference in total morphological score, somite number and embryo protein content compared with embryos grown only in WRS ( $p>0.05)$ (Fig. 1). However,

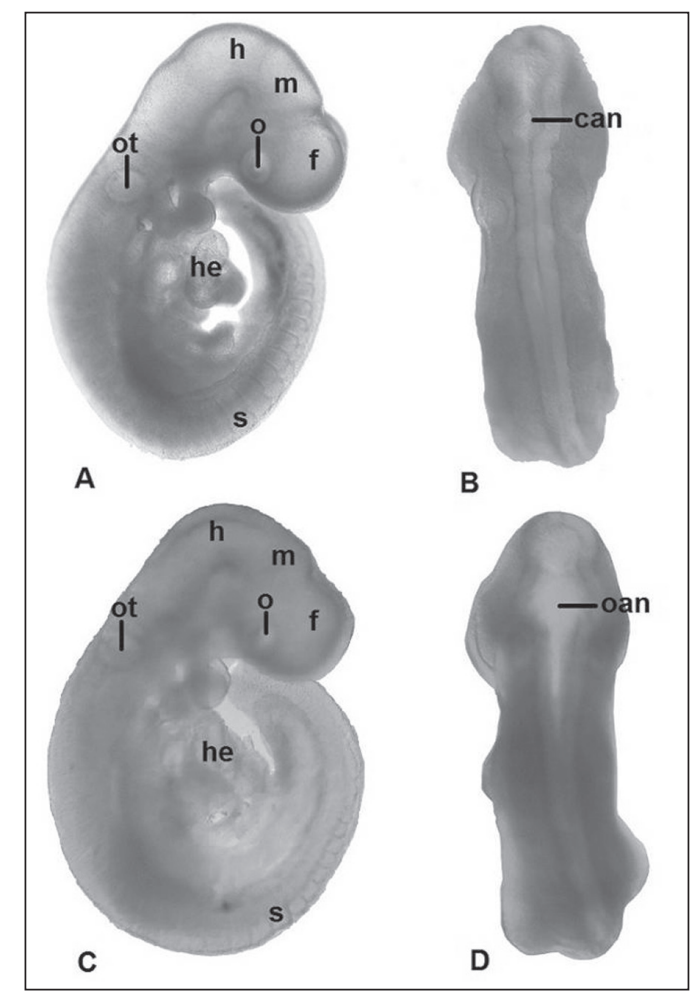

Figure 1. Rat embryos outside of the yolk sac at 11.5 days of gestation following 48-h culture period in whole rat serum (control group) (A, B) and whole rat serum $+1000 \mathrm{IU} / \mathrm{mL}$ interferon beta- $1 \mathrm{a}$ (C, D); $\mathrm{f}$ - forebrain; $\mathrm{m}$ - midbrain, $\mathrm{h}$ - hindbrain; 0 - optic vesicle; ot - otic vesicle; he — heart; s — somite; oan — open anterior neuropore, can — closed anterior neuropore.

when compared with control group, a significant retardation in yolk sac diameter, crown rump length and head length parameters in two experimental groups was determined $(p<0.05)$. Related results are given in Table 1.

Parameters related to the nervous system were also considered (Table 2). In the experimental groups, the number of embryos that had growth retardation in parameters related to nervous system (caudal neural tube, hindbrain, midbrain, forebrain and olfactory system) were larger compared with the control group. This numerical excess was not statistically significant; however, most of the embryos exposed to IFN $\beta$ - $1 \mathrm{a}$ and IFN $\beta-1 \mathrm{~b}$ had open posterior neural tubes, anterior neuoropores and poor neural system development (Fig. 1).

\section{DISCUSSION}

Various disease-modifying drugs, including IFN $\beta$-1a and IFN $\beta-1 b$, glatiramer acetate, natalizumab, mitoxantrone, and fingolimod that are licensed worldwide to reduce the frequency of clinical attacks with the expectation of slowing disability progression [14]. 
Table 1. In vitro embryonic development in control and interferon beta (IFN $\beta$ ) groups

\begin{tabular}{|c|c|c|c|c|c|c|c|c|c|c|c|}
\hline & \multicolumn{3}{|c|}{ Control group } & \multicolumn{4}{|c|}{1000 IU/mL IFN $\beta-1 \mathrm{a}$} & \multicolumn{4}{|c|}{$1000 \mathrm{IU} / \mathrm{mL}$ IFN $\beta-1 \mathrm{~b}$} \\
\hline & Mean \pm SD & Min & Max & Mean \pm SD & Min & Max & $\mathbf{P}$ & Mean \pm SD & Min & Max & $\mathbf{P}$ \\
\hline $\begin{array}{l}\text { Total } \\
\text { morphological } \\
\text { score }\end{array}$ & $56.25 \pm 3.04$ & 51 & 60 & $56.17 \pm 1.32$ & 54 & 58 & 0.997 & $53.56 \pm 2.46$ & 49 & 57 & 0.57 \\
\hline $\begin{array}{l}\text { Somite } \\
\text { number }\end{array}$ & $22.2 \pm 2.45$ & 19 & 25 & $21.88 \pm 1.13$ & 20 & 23 & 0.833 & $21.66 \pm 0.86$ & 21 & 23 & 0.902 \\
\hline $\begin{array}{l}\text { Yolk sac } \\
\text { diameter } \\
{[\mathrm{mm}]}\end{array}$ & $4.79 \pm 0.37$ & 4.26 & 5.58 & $4.08 \pm 0.32$ & 3.59 & 4.43 & $000^{* *}$ & $4.12 \pm 0.32$ & 3.49 & 4.54 & $001^{*}$ \\
\hline $\begin{array}{l}\text { Crown-rump } \\
\text { length [mm] }\end{array}$ & $3.78 \pm 0.43$ & 3.07 & 4.35 & $3.34 \pm 0.10$ & 3.21 & 3.57 & $008^{*}$ & $3.29 \pm 0.19$ & 3.02 & 3.58 & $003^{*}$ \\
\hline $\begin{array}{l}\text { Head length } \\
{[\mathrm{mm}]}\end{array}$ & $1.59 \pm 0.10$ & 1.46 & 1.74 & $1.44 \pm 0.03$ & 1.40 & 1.50 & $000^{* *}$ & $1.47 \pm 0.04$ & 1.40 & 1.55 & $002^{*}$ \\
\hline $\begin{array}{l}\text { Embryo } \\
\text { protein } \\
\text { content [mg] }\end{array}$ & $187.27 \pm 45.77$ & 136.77 & 242.83 & $182.68 \pm 7.09$ & 168.45 & 194.62 & 0.935 & $184.83 \pm 13.43$ & 161.57 & 201.51 & 0.981 \\
\hline
\end{tabular}

*One Way Analysis of Variance (ANOVA) was applied; $p<0.05$; SD — standard deviation

Table 2. The morphological score of brain parameters (caudal neural tube, hindbrain, midbrain, forebrain, olfactory system) in control group, $1000 \mathrm{IU} / \mathrm{mL}$ IFN $\beta$-1a and $1000 \mathrm{IU} / \mathrm{mL} \mathrm{IFN} \beta$-1b groups

\begin{tabular}{|c|c|c|c|c|c|c|c|c|c|c|c|c|c|c|c|c|c|c|c|c|c|c|c|c|c|c|}
\hline \multirow[b]{2}{*}{$\begin{array}{l}\text { Morphological } \\
\text { score }\end{array}$} & \multirow[t]{2}{*}{$\mathbf{N}$} & \multicolumn{5}{|c|}{ Caudal neural tube } & \multicolumn{5}{|c|}{ Hindbrain } & \multicolumn{6}{|c|}{ Midbrain } & \multicolumn{5}{|c|}{ Forebrain } & \multicolumn{4}{|c|}{$\begin{array}{l}\text { Olfactory } \\
\text { system }\end{array}$} \\
\hline & & 0 & 12 & 3 & 4 & 5 & 0 & 1 & 2 & 34 & 5 & 0 & 1 & 2 & 3 & 4 & 5 & 0 & 1 & 2 & 4 & 5 & 0 & 1 & 2 & 3 \\
\hline Control group & 10 & & & 5 & 5 & & & & & 4 & 5 & & & & 1 & 5 & 4 & & & & 6 & 4 & & & 4 & 6 \\
\hline $\begin{array}{l}1000 \mathrm{IU} / \mathrm{mL} \\
\text { IFN } \beta-1 \mathrm{a}\end{array}$ & 9 & & & 7 & 2 & & & & & 2 & & & & & & 9 & & & & 1 & 7 & 1 & & 2 & 7 & \\
\hline $\begin{array}{l}1000 \mathrm{IU} / \mathrm{mL} \\
\mathrm{IFN} \beta-1 \mathrm{~b}\end{array}$ & 9 & & & 9 & & & & & & 3 & & & & & 3 & 6 & & & & & 3 & 6 & & 9 & & \\
\hline
\end{tabular}

$\mathrm{N}$ - the number of embryo; Caudal neural tube - 0 : Neural layer or neural folds created, 1: Neural layer closed but uncombined with neural fold, 2: Neural folds combined at 4-5 somites level, 3: Posterior neuropore is shaped but open, 4: A small aperture in the posterior neuropore, 5: Posterior neuropore is closed; Hindbrain - 0: Neural layer was formed, 1: Neural fold is V-shaped, 2: Neural fold is U-shaped, 3: Anterior neuropore is formed but open, 4: Anterior neuropore is closed, rhombencephalon is shaped, 5 : Upper edge of the fourth ventricle and pons inosculated; Midbrain — 0: Mesencephalic brain folds or neural layer formed, 1: Neural fold is V-shaped, 2: Neural fold is U-shaped, 3: Mesencephalic fold partially merged,

4: Mesencephalon is merged, 5: A chamber is formed between the rhinencephalon and the mesencephalon; Forebrain — 0: Neural layer is formed, 1: Neural fold is V-shaped, 2: Neural fold is U-shaped, 3: Prosencephalic fold partially merged, 4: Prosencephalon is merged, 5: Telencephalic evagination formed; Olfactory system — 0 : No symptoms, 1: Olfactory layer is formed, 2: Olfactory layer is surrounded, 3: Olfactory protrusion is obvious

Great majority of studies related to IFNs have been directed towards to determination of their effects on diseases and biological structures $[9,39]$. At present, recommendation to quit the use of IFN $\beta$ during pregnancy is based on findings from animal studies; in primates, administration of up to 100 times the recommended weekly human dose of IFN $\beta$ (based upon a body surface area comparison) was not associated with teratogenicity or adverse effects on foetal development [18]. In spite of these data, the FDA has given IFN $\beta$ drugs a pregnancy category $C$ rating, based on experimental primate studies showing abor- tifacient activity at 2-100 times the corresponding human dose [12].

By virtue of the first trimester of pregnancy is characterised by precisely choreographed gene expression and rapid cell division that lays the foundation for later foetal growth and development [7], it is completely possible that early IFN exposure may have affect these early processes to cause later prematurity and decreased growth.

To the best of our knowledge, there is no embryo culture study to investigate the teratogenic effects of IFN $\beta$ - $1 \mathrm{a}$ and IFN $\beta$ - $1 \mathrm{~b}$ on embryos. 
In this study, in order to determine the level of development of cultured embryos, total morphological scoring method was used [23]. When developments of embryos were evaluated, no significant differences were detected among the control and experimental groups. On the other hand, when yolk sac diameter, crown rump length and head length were evaluated, significant differences were determined among the control and experimental groups. In the current literature, the yolk sac diameters of control embryos (11.5 days of age) were reported as $3.17 \pm 0.14 \mathrm{~mm}$ [31], $5.0 \pm 0 \mathrm{~mm}[42], 5.70 \pm 0.38 \mathrm{~mm}$, respectively [45]. In this study, yolk sac diameter was calculated as $4.79 \pm 0.37 \mathrm{~mm}$ in control group and $4.08 \pm 0.32 \mathrm{~mm}$, $4.12 \pm 0.32 \mathrm{~mm}$ in experimental IFN $\beta-1 \mathrm{a}$ and IFN $\beta$-1 $1 \mathrm{~b}$ groups, respectively. In the current literature, the value of crown-rump lengths were reported to range between $2.80 \pm 0.11$ and $5.4 \pm 0.18 \mathrm{~mm}$ in embryos of control groups (11.5 days of age) [31, 42, 45]. In our study, the average crown-rump lengths were determined in the control group as $3.78 \pm$ $\pm 0.43 \mathrm{~mm}$, and $3.34 \pm 0.10 \mathrm{~mm}, 3.29 \pm 0.19 \mathrm{~mm}$ in experimental IFN $\beta-1 \mathrm{a}$ and IFN $\beta-1 \mathrm{~b}$ groups, respectively. In another study, mean head length of embryos in the control group was reported as $2.0 \mathrm{~mm}$ [36], while in our study, head lengths of the embryos were measured as $1.59 \pm 0.10 \mathrm{~mm}$ in the control group, $1.44 \pm$ $\pm 0.03 \mathrm{~mm}$ and $1.47 \pm 0.04 \mathrm{~mm}$ in experimental IFN $\beta$-1 $\mathrm{a}$ and IFN $\beta$-1 $1 \mathrm{~b}$ groups, respectively. As there was no study to use IFN in embryo culture currently, we cannot compare our experimental results. Thus, in our opinion, the decreased results in experimental groups may be the result of IFN use, while the discrepancy of the results of control group may be due to diversity of working environment, the researchers and rat species.

Studies in humans, Amato et al. [2] demonstrated that IFN $\beta$ use during pregnancy did not increase the risk of spontaneous miscarriage; however, it was related to low birth weight and short birth length. Boskovic et al. [4] showed that the usage of IFN $\beta$ in the first 3 months of pregnancy caused foetal loss and low birth weight when compared to healthy pregnant control group and unexposed pregnant women with MS. On the contrary, Hellwig et al. [17] stated that congenital anomalies were in the normal rate in pregnant women used IFN $\beta$ and concluded the drug not to have any teratogenic risk. Sandberg-Wollhem et al. [40] investigated the teratogenic effects of IFN $\beta$ - 1 a on $425 \mathrm{MS}$ patients treated with IFN $\beta-1 \mathrm{a}$ in the process of pregnancy by injection under the skin for at least 45 days. They determined 49 spontaneous abortions, 4 stillbirth and 4 children with congenital anomalies; the incidence of spontaneous abortion and congenital anomalies have been noted within normal range.

In this study, the similarities between the results related to the total morphological score and somites number in all groups demonstrated that mentioned doses of IFN $\beta-1 \mathrm{a}$ and IFN $\beta$ - $1 \mathrm{~b}$ had no teratogenic effect on the embryos. Considering this aspect; our results were consistent with Hellwig et al. [17]. However, the significant differences between the control and experimental groups in terms of yolk sac diameter, crown-rump length and head length parameters revealed that embryos growing in IFN $\beta-1 a$ and IFN $\beta-1 \mathrm{~b}$ added medium had lower body size. When evaluated in this respect, our results were consistent with previous studies investigating the relationship between the use of IFN $\beta$ and its teratogenicity during pregnancy $[2,4]$. They determined that using IFN $\beta$ during the first 3 months of pregnancy caused low birth weight and short stature compared to the healthy control group.

In the treatment of MS, the effects of IFN $\beta$ - $1 \mathrm{a}$ and IFN $\beta$ - $1 \mathrm{~b}$ on developing embryos during pregnancy are unclear and also being a disease involving the nervous system; in our opinion these drugs can potentially affect the nervous system of embryos, in case of use during pregnancy. IFNs are naturally produced inhibitors of cell growth that can also affect differentiated cell function [38]. IFNs have been previously shown to inhibit the hormone-induced synthesis of several enzymes $[3,19,32]$ and the differentiation and proliferation of glial cells [1,33]. Researchers investigated the effect of IFN-alpha/beta on the expression of glycerol phosphate dehydrogenase (GPDH) in both C6 glioma cells and pure cultures of oligodendrocytes. GPDH is a biochemical marker for oligodendrocytes and is known to be developmentally regulated and steroid inducible. A pre-treatment of these cells with $75 \mathrm{U} / \mathrm{mL}$ of IFN-alpha/beta resulted in an inhibition of the hydrocortisone induction of GPDH enzymatic activity by $50 \%$ and $40 \%$ in $\mathrm{C} 6$ cells and oligodendrocytes, respectively. They also found that IFN impaired the accumulation of GPDH mRNA in both cell types. These results demonstrate that IFNs are capable of modifying the cellular response to hormones in cells of neuroepithelial origin, and suggest the possibility that IFNs may be able to influence the development and function of the brain [33]. Thus, embryos cultured 
in medium with IFN $\beta-1 \mathrm{a}$ and IFN $\beta-1 \mathrm{~b}$ were evaluated in terms of development of the nervous system. We determined numerical redundancy in the embryos of the experimental groups pointing out retardation in the nervous system. Therefore, in our opinion, IFN $\beta$ - $1 \mathrm{a}$ and IFN $\beta-1 \mathrm{~b}$ may affect the development of the neural system. The redundancy in the number of the embryos that have poorer neural system development in the experimental groups may be considered in later studies.

\section{Limitations of the study}

Our study had some limitations that make it difficult to generalise the results for all of the conditions. The first limitation of our study was the dose of IFN $\beta$; the effect of different doses of IFN $\beta$ on embryo development was not investigated in this study. The second limitation was the assessment criteria. We didn't use histological examination; we evaluated embryonic development by using morphologic score, protein content and morphometric measurements.

\section{CONCLUSIONS}

Together with a wide range of other in vitro studies dealing with the teratogenicity of several different molecules, the present findings suggest that the rat post-implantation embryo culture system is a very useful method for teratological studies and also particularly suitable for the assessment of specific effects on morphogenetic events occurring during early organogenesis in mammalian embryos. Consequently, our study demonstrated that $1000 \mathrm{IU} / \mathrm{mL} \mathrm{IFN} \beta-1 \mathrm{a}$ and $1000 \mathrm{IU} / \mathrm{mL}$ IFN $\beta$ - $1 \mathrm{~b}$ did not have macroscopic teratogenic effects on the growth of embryos. However, lower values in yolk sac diameter, crown-rump length and head length parameters showed that indicated doses of IFN $\beta-1 \mathrm{a}$ and IFN $\beta-1 \mathrm{~b}$ caused growth retardation. As this is the first study using IFN $\beta$ in vitro embryo culture technique, the future studies planned with different doses of IFN $\beta$ and effects of IFN $\beta$ using at different stages of pregnancy will contribute to the literature.

\section{REFERENCES}

1. Abreu SL (1985) Interferon in experimental autoimmune encephalomyelitis (EAE) effects of exogenous interferon on the antigen-enhanced adoptive transfer of EAE. Int Archs Allergy Appl Immunol, 76: 302-307. doi: 10.1159/000233711.

2. Amato MP, Portaccio E, Ghezzi A, Hakiki B, Zipoli V, Martinelli V, Moiola L, Patti F, La Mantia L, Mancardi GL, Solaro C, Tola MR, Pozzilli C, De Giglio L, Totaro R, Lugaresi A, Di Tommaso V, Paolicelli D, Marrosu MG, Comi G, Pellegrini F,
Trojano M (2010) Pregnancy and fetal outcomes after interferon-beta exposure in multiple sclerosis. Neurology, 75: 1794-1802. doi: 10.1212/WNL.0b013e$3181 \mathrm{fd} 62 \mathrm{bb}$.

3. Beck G, Poindron P, Illinger $D$, Beck JP, Ebel JP, Falcoff $R$ (1974) Inhibition of steroid inducible tyrosine aminotransferase by mouse and rat interferon in hepatoma tissue culture cells. FEBS Lett, 48: 297-300. doi: 10.1016/00145793(74)80490-4.

4. Boskovic R, Wide R, Wolpin J, Bauer J, Koren G (2005) The reproductive effects of beta interferon therapy in pregnancy. Neurology, 65: 807-811. doi: 10.1212/01. wnl.0000180575.77021.c4.

5. Cann AJ (1997) Principles of molecular virology. 2nd Ed. Academic Press, London.

6. Confavreux C, Aimard G, Devic M (1980) Course and prognosis of multiple sclerosis assessed by the computerized data processing of 349 patients. Brain, 103: 281-300. doi: 10.1093/brain/103.2.281.

7. Cunningham FG, Leveno KJ, Bloom SL, Hauth JC, Rouse DJ, Spong CY (2010) Fetal growth and development. In: Williams Obstetrics, 23 Ed. McGraw-Hill, New York.

8. Dahl J (2008) Multiple Sclerosis and pregnancy: pregnancy, delivery and birth outcome in women with multiple sclerosis. Phd Thesis, University of Bergen, Bergen.

9. Damek DM, Shuster EA (1997) Pregnancy and multiple sclerosis. Mayo Clin Proc, 72: 977-989. doi: 10.4065/72.10.977.

10. Diaz MO, Bohlander S, Allen G (1996) Nomenclature of the human interferon genes. J Interferon Cytokine Res, 16: 179-180. doi: 10.1089/jir.1996.16.179.

11. Ertekin $T$, Ulger $H$, Nisari $M$, Unur $E$, Şahin $U$, Elmali $F$ (2011) Effects of Angiostatin on in vitro Embryonic Rat Development. Kafkas Univ Vet Fak Derg, 17: 843-847. doi: 10.9775/kvfd.2011.4637.

12. Ferro S, Esposito F, Pretta S, Ragni N (2006) Fetal risks related to the treatment of multiple sclerosis during pregnancy and breastfeeding. Expert Rew Neurother, 6: 1823-1831. doi: 10.1586/14737175.6.12.1823.

13. Ferro S, Pretta S, Ragni N (2004) Multiple sclerosis: management Issues during pregnancy. Eur J Obster Gynecol Reprod Biol, 115: 3-9. doi: 10.1016/j.ejogrb.2003.10.020.

14. Freedman MS, Hughes B, Mikol DD, Bennett R, Cuffel B, Divan V, LaVallee N, AL-Sabbagh A (2008) Efficacy of disease-modifying therapies in relapsing remitting multiple sclerosis: a systematic comparison. Eur Neurol, 60: 1-11. doi: 10.1159/000127972.

15. Hardy MP, Owczarek CM, Jermiin LS, Ejdebäck M, Hertzog PJ (2004) Characterization of the type I interferon locus and identification of novel gene. Genomics, 84: 331-345. doi: 10.1016/j.ygeno.2004.03.003.

16. Hauser SL, Goodin DS (2005) Multiple sclerosis and other demyelinating diseases. In: Kasper DI, Braunwald E, Fauci A, Hauser SI, Longo DI, Jameson Jl eds. Harrison's Principles of Internal Medicine. 16th Ed. Mcgraw-Hill Comp, New York, pp. 2461-2470.

17. Hellwig K, Haghikia A, Rockhoff M, Gold R (2012) Multiple sclerosis and pregnancy: experience from a nationwide database in Germany. Ther Adv Neurol Disord, 5: 247-253. doi: $10.1177 / 1756285612453192$. 
18. Houtchens MK, Kolb CM (2013) Multiple sclerosis and pregnancy: therapeutic considerations. J Neurol, 260: 1202-1214. doi: 10.1007/s00415-012-6653-9.

19. Illinger D, Coupin G, Richards M, Poindron P (1976) Rat interferon inhibits steroid inducible glycerol-3-phosphate dehydrogenase synthesis in a rat glial cell line. FEBS Lett, 64: 391-395. doi: 10.1016/0014-5793(76)80334-1.

20. Isaacs A, Lindenmann J (1957) Virus interference: the Interferon. Proc R Soc Lond B Biol Sci, 147: 258-267. doi: 10.1098/rspb.1957.0048.

21. Jacobs L, Johnson KP (1994) A brief history of the use of interferons as treatment of multiple sclerosis. Arch Neurol, 51: 1245-1252. doi: 10.1001/archneur. 1994. 00540240089022.

22. Jacobs L, Malley JA, Freeman A, Ekes R (1981) Intrathecal interferon reduces exacerbations of multiple sclerosis. Science, 214: 1026-1028. doi: 10.1126/science.6171035.

23. Kabat EA, Glusman M, Kanaub V (1948) Quantitative estimation of the albumin and gamma globulin in normal and pathologic cerebrospinal fluid by immunochemical methods. Am J Med, 4: 653-662. doi: 10.1016/S00029343(48)90389-1.

24. Kayaalp SO (2005) Rasyonel Tedavi Yönünden Tıbbi Farmakoloji, Cilt 1, Hacettepe-Taş, 11. Baskı. Ankara.

25. Khan OA, Tselis AC, Kamholz JA, Garbern JY, Lewis RA, Lisak RP (2001) A prospective, open-label treatment trial to compare the effect of IFN beta-1a (Avonex), IFNbeta-1b (Betaseron), and glatiramer acetate (Copaxone) on the relapse rate in relapsing-remitting multiple sclerosis. Eur J Neurol, 8: 141-148. doi: 10.1046/j.1468-1331.2001.00189.x.

26. Loma I, Heyman R (2011) Multiple sclerosis: pathogenesis and treatment. Curr Neuropharmacol, 9: 409-416. doi: 10.2174/157015911796557911.

27. Lublin FD, Reingold SC (1996) Defining the clinical course of multiple sclerosis: results of an international survey. National Multiple Sclerosis Society (USA) Advisory Committee on Clinical Trials of New Agents in Multiple Sclerosis. Neurology, 46: 907-911. doi: 10.1212/WNL.46.4.907.

28. New DAT (1978) Whole embryo culture and the study of mammalian embryos during organogenesis. Biol Rev Camb Philos Soc, 53: 81-122. doi: 10.1111/j.1469-185X.1978. tb00993.x.

29. New DAT, Stein KF (1964) Cultivation of post-Implantation mouse and rat embriyos on plasma clots. J Embryol Exp Morphol, 12: 101-111.

30. Nisari M, Ulger $H$ (2010) The embryo culture techniques. J Health Sciences, 19: 216-225.

31. Nisari M, Ulger H, Unur E, Karaca O, Ertekin T (2014) Effect Of Interleukin 12 (IL-12) on Embryonic Development and Yolk Sac Vascularisation. Bratisl Lek Listy, 115: 532-537. doi: 10.4149/BLL_2014_103.

32. Passaquin AC, Coupin G, Poindron P (1986) Rat interferon inhibits catecholamine-inducible synthesis of lactic dehydrogenase in rat glial tumoral C6 cells. J Interferon Res, 6: 71-77. doi: 10.1089/jir.1986.6.71.
33. Passaquin AC, Coupin G, Schreier WA, Poindron P, Cole RA, de Vellis J (1989) Interferon inhibits the accumulation of glycerol phosphate dehydrogenase mRNA in oligodendrocytes and C6 cells. Neurochem Res, 14: 987-993. doi: 10.1007/BF00965933.

34. Poser S, Poser W (1983) Multiple Sclerosis and gestation. Neurology, 33: 1422-1427. doi: 10.1212/WNL.33.11.1422.

35. Ramagopalan S, Yee I, Byrnes J, Guimond C, Ebers G, Sadovnick D (2012) Term pregnancies and the clinical characteristics of multiple sclerosis: a population based study. J Neurol Neurosurg Psychiatry, 83: 793-795. doi: 10.1136/jnnp-2012-302848.

36. Robinson JF, Verhoef $A$, van Beelen VA, Pennings JL, Piersma AH (2012) Dose-response analysis of phthalate effects on gene expression in rat whole embryo culture. Toxicol Appl Pharmacol, 264: 32-41. doi: 10.1016/j.taap.2012.07.015.

37. Rolak LA (2003) Multiple sclerosis: it's not the disease you thought it was. Clin Med Res. 1: 57-60.

38. Rossi GB (1985) Interferons and cell differentiation. In: Gresser I. ed. Interferon 6. Academic Press, London, pp. 31-50.

39. Sadovnick AD, Baird PA (1985) Reproductive counselling for MS patients. Am J Med Genet, 20: 349-354. doi: 10.1002/ajmg.1320200218.

40. Sandberg-Wollheim M, Alteri E, Moraga MS, Kornmann G (2011) Pregnancy outcomes in multiple sclerosis following subcutaneous interferon beta-1a therapy. Mult Scler, 17: 423-430. doi: 10.1177/1352458510394610.

41. Stewart TA (2003) Neutralizing interferon alpha as a therapeutic approach to autoimmune diseases. Cytokine Growth Factor Rev, 14: 139-154. doi: 10.1016/S1359-6101(02)00088-6.

42. Tekinarslan ii, Unur E, Ulger $\mathrm{H}$, Ekinci $\mathrm{N}$, Ertekin $\mathrm{T}$, Hacıalioğulları M, Arslan S (2011) The Effects of FGF-9 on In Vitro Embryonic Development. Balkan Med J, 28: 18-22. doi: 10.5174/tutfd.2009.02019.2.

43. The IFNB Multiple Sclerosis Study Group and The University of British Columbia MS/MRI Analysis Group (1995) Interferon beta-1 $\mathrm{b}$ in the treatment of multiple sclerosis: final outcome of the randomized controlled trial. Neurology, 45: 1277-1285. doi: 10.1212/WNL.45.7.1277.

44. Tillman AJB (1950) The effect of pregnancy on multiple sclerosis and its management. Res Publ Assoc Res Nerv Ment Dis, 28: 548-582.

45. Torun YA, Ozdemir MA, Ulger H, Nisari M, Akalın H, Patıroglu P, Ozkul Y, Onal M, Karakukcu M (2014) Erythropoietin improves brain development in short-term hypoxia in rat embryo cultures. Brain Dev, 36: 864-869. doi: 10.1016/j. braindev.2014.01.005.

46. Weinshenker BG, Bass B, Rice GP, Noseworthy J, Carriere W, Baskerville J, Ebers GC (1989) The natural history of multiple sclerosis: a geographically based study. I. Clinical course and disability. Brain, 112: 133-146. doi: 10.1093/ /brain/112.1.133.

47. Zanon RG, Pierucci A, Alexandre LR (2009) Interferon beta and glatiramer acetate induce proliferation of Schwann cells in vitro. Acta Neurobiol Exp, 69: 146-152. 